\title{
Capital Expenditure and Firm Performance Evidence from Albanian Construction Sector
}

\author{
Msc Ester Taipi \\ Accountant at private business, Elbasan, Albania
}

PhD Valbona Ballkoci

Lecturer at Finance and Accounting Department, Faculty of Economy

University of Elbasan “Aleksandër Xhuvani”, Elbasan, Albania

Doi: 10.19044/esj.2017.v13n28p231 URL:http://dx.doi.org/10.19044/esj.2017.v13n28p231

\begin{abstract}
This paper investigates the link between the capital expenditures and firm performance of Albanian firms in the construction sector, based on the data collected from 30 firms between 2008 and 2015.

The study took into consideration the fact that capital expenditures is not the only variable that influences the model and as a consequence other variables affecting financial performance were analyzed, which are: leverage ratio and firm size. The linear regression model was used to analyze this relationship. According to the survey the model was explained $63 \%$ by the chosen variables. The regression analysis indicated that capital expenditures and leverage ratio are statistically significant and positively correlated with the financial performance of the firm. On the other side, the size of the firm is not a statistically significant variable and it is also negatively correlated with firm performance.
\end{abstract}

Keywords: Capital expenditure, firm performance, leverage, firm size, Albania

\section{Introduction}

Capital investment decisions are among the most important decisions taken by firms because they affect shareholders wealth, the long-term perspective of the firm's survival, a competitive advantage and also the overall economic welfare of society.

Firms around the world invest considerable amounts of money on capital expenditures in order to increase financial performance, maximize revenue, and maintain the competitive position in the market. Capital Expenditures are the category of assets that generally indicate the most important use of a company's resources. Investments in fixed assets such as 
buildings, equipment and machinery increase the firm's production capacity in order to increase the long-term profit of the company.

The main purpose of this paper is to provide empirical evidence on the relationship between capital expenditure and firm performance in Albanian Construction firms. The study seeks to determine the effect of capital expenditure on the financial performance of 30 Albanian firms in the construction sector for the period between 2008 and 2015.

\section{Problem Statement state}

Lev and Thiagarajan (1993) state that capital investments represent an important factor that can serve as a signal in predicting the future profitability of the firm and stock returns. The review of different literatures highlights two contradictory conclusions between them. Authors such as McConnell and Muscarella (1985), Chan, Martin and Kensinger (1990), Ching Hai, Hsiang Chen and Yen -Sheng (2006), based on the results of their studies highlight a positive relationship between capital expenditure and firm performance. Meanwhile, on the other hand, the findings of the works of the authors Abarbanell and Bushee (1997), Titman, Wei and Xie (2004), Chen, Yao, Yu and Zhang (2008), Cooper, Gulen and Schill (2008) identify a negative relationship between capital expenditure and firm performance.

This knowledge gap is even more evident in the Albanian economy where there is little empirical effort to understand the effects of capital investments on a company's financial performance.

\section{Objective of the study}

The main objective of the research is to analyze whether there is a statistically significant positive or negative link between firm capital expenditure and their financial performance in Albanian construction sector.

While other objectives of this research are:

- To examine the relationship between debt ratio and the financial performance.

- To examine the relationship between firm size and financial performance.

\section{Research Questions}

1) Do capital expenditures affect the firm's performance?

2) Does the firm's size affect the firm's performance?

3) Does the firm's leverage ratio affect the firm's performance?

4) What is the nature of these influences? Is it positive or negative?

5) Do Albanian's construction firms carry out R\&D expenditures? 


\section{Hypothesis Statement}

Similarly, the following research hypotheses have been formulated in an attempt to provide empirical evidence on the existence of relationship between the variables of the study:

H0: There is no significant relationship between capital expenditures (as measured using net book value of PPE) and firm performance.

$\mathrm{H} 1$ : There is a significant relationship between capital expenditures and firm performance.

\section{Literature Review}

Capital expenditures arise when a business spends money on buying fixed assets or adding value to an existing fixed asset to a useful life that extends beyond the taxable year (McConnell and Muscarella, 1985).

The following review of empirical studies presents the findings of studies that evaluate financial performance using both methods such as accounting and stock return.

McConnell and Muscarella (1985) show that forecasts of planned growth in capital investments are generally associated with very high stock returns.

Chung, Wright and Charoenwong (1998) argue that financial performance measured by stock price reaction depends critically on market valuation in relation with the quality of a company's capital expenditure decisions. They assume that firms with high-quality investment opportunities, announcements for increasing capital spending decisions are associated with increasing stock prices in the firm.

Ching Hai, Hsiang, Chen and Yen-Sheng (2006) examine the relationship between capital expenditures and corporate profits for 357 manufacturing firms listed on the Taiwan Stock Exchange over a 10-year period. The findings show a positive relationship between capital expenditure and future corporate profits.

Titman, Wei and Xie (2004) conclude that there is a negative relationship between capital investment and future stock returns. This negative link is more emphasized in firms with higher cash flow and lower debt ratios.

Chen, Yao, Yu and Zhang (2008) consider the effect of corporate asset growth compared to return on equity by using capital market data in the Pacific Basin region. They find a negative link between asset growth and stock returns during the period from 1981 to 2004.

Kim, S. (2001) examines the financial performance of US manufacturing firms. Based on a sample of an average of 515 observations per year during the period 1976-1989, Kim did not report any linear link between capital expenditure and future earnings for the general sample. 


\section{Research Methodology}

This paper will follow a descriptive study plan. The current research plan is chosen because the study is not limited to data collection and descriptions, but seeks to determine the existence of a relationship between two variables that are capital expenditures and financial performance of Albanian companies. These data have been provided by the National Center of Business Registration.

\section{Sample Selection}

The study population will be firms in the construction sector operating in the Albanian market, for the period from 2008 to 2015. For the purpose of the study only 30 companies were listed and analyzed actively during the review period due to lack of sufficient data. The study is based on financial data. The main sources of this data are financial statements, such as income statement and balance sheet. The data for the analysis were collected from the annual reports of construction sector firms for the period from 2008 to 2015. The study focuses only on a certain sector in order to reach an accurate conclusion and not a general one.

\section{Variables of the Model}

In accordance with the objective of the research this study will use the linear regression model. A linear regression is an appropriate analysis when the goal of research is to investigate the relationship among variables. Therefore, as an independent variable, we will use capital expenditures. In addition, there are taken other independent variables that will complete the study to reach the fullest conclusion. These consist of the leverage ratio and size of the firm, as other factors affecting financial performance. The equation of the regression model is as follows:

$\mathrm{FP}=\beta 0+\beta 1 \mathrm{CAPEX}+\beta 2(\mathrm{X} 2)+\beta 3(\mathrm{X} 3)+\mathrm{e}$

FP is Financial Performance measured by ROA, (Return on assets).

Return on Assets Ratio (ROA) $=$ Net Income / Average Total Assets

CAPEX = Capital Expenditure (as measured using net book value of PPE). $\beta 0=$ constant or intercept.

$\beta 1-\beta 3=$ the regression coefficients.

X2 -Leverage: Total debt / Total assets.

X3-Firm size (measured by the logarithm of total assets).

$\mathrm{e}=$ the model error term (the model's level of importance), a randomlydistributed random variable, expresses the deviations of the observed values at $\mathrm{y}$ from its expected values calculated on the side of the regression equation.

Capital expenditures will be measured using the values of long-term assets during the review period. Financial performance will be measured using 
asset return (ROA). The study will compare the ROA of the year after making capital expenditures in order to allow the assets to realize return on investment.

The other variables tested in this model are the leverage rate and the size of the firm. The leverage will be measured by taking the ratio of total debt to total assets while the size of the firm will be determined by the logarithm $(\mathrm{Log})$ of the total assets.

\section{Data Analysis in the Regression Model}

The study was conducted in 30 Albanian construction firms. In this study, the linear regression method was used through the SPSS 21.

Table 1. Descriptive Statistics

\begin{tabular}{|c|c|c|c|}
\hline & Mean & Std. Deviation & $\mathrm{N}$ \\
\hline ROA & .1287 & .2314 & 30 \\
\hline Leverage & .8352 & 1.0951 & 30 \\
\hline Firm size & 8.6151 & .7953 & 30 \\
\hline CAPEX & .8040 & 1.7216 & 30 \\
\hline
\end{tabular}

Table 1 gives the average and standard deviation for the four variables analyzed in the 30 companies surveyed during the period 20082015.

Table 2. Model Summary

\begin{tabular}{|c|c|c|c|c|}
\hline Model & $\mathrm{R}$ & $\mathrm{R}$ Square & Adjusted R Square & $\begin{array}{c}\text { Std. Error of the } \\
\text { Estimate }\end{array}$ \\
\hline 1 & $.793^{\mathrm{a}}$ & .630 & .587 & .148758800316321 \\
\hline \multicolumn{4}{|r}{ a. Predictors: (Constant), CAPEX, Leverage, Log Assets } \\
\hline
\end{tabular}

$\mathrm{R}$-squared is the coefficient of determination for multiple regressions. This coefficient varies from 0 to 1 . Its values close to 1 indicate a high degree of approximation while values close to 0 speak for a poor approximation of the linkage to the regression equation.

According to the data shown in Table 2, the value of square $\mathrm{R}$ is 0.630 which means that $63 \%$ of the financial performance is explained by three variables. This means that $37 \%$ of the model is explained by other variables that affect the performance of these firms and can be taken into consideration in other studies.

Table 3. ANOVA

\begin{tabular}{|c|c|c|c|c|c|c|}
\hline \multicolumn{2}{|c|}{ Model } & Sum of Squares & Df & Mean Square & F & Sig. \\
\hline \multirow{3}{*}{1} & Regression & .978 & 3 & .326 & 14.730 & $.000^{\mathrm{b}}$ \\
\cline { 2 - 7 } & Residual & .575 & 26 & .022 & & \\
\cline { 2 - 7 } & Total & 1.553 & 29 & & & \\
\hline \multicolumn{7}{|c|}{ a. Dependent Variable: ROA } \\
\hline \multicolumn{7}{|c|}{ b. Predictors: (Constant), CAPEX, leverage, firm size } \\
\hline
\end{tabular}


Table 3 shows the variance analysis of the model. It can be seen that the value of $\mathrm{p}$ is less than 0.05 and Fisher's observed value is greater than the critical value of $\mathrm{F}$ (2.98) for the confidence interval of 95\%. In conclusion, we can say that the model is statistically significant and hypothesis 1 stands. Thus, there is a positive relationship between capital expenditure and firm performance.

Table 4. Regression coefficients

\begin{tabular}{|c|c|c|c|c|c|c|}
\hline \multirow{2}{*}{\multicolumn{2}{|c|}{ Model }} & \multicolumn{2}{|c|}{ Unstandardized Coefficients } & \multirow{2}{*}{$\begin{array}{c}\begin{array}{c}\text { Standardized } \\
\text { Coefficients }\end{array} \\
\text { Beta }\end{array}$} & \multirow[b]{2}{*}{$\mathrm{t}$} & \multirow[b]{2}{*}{ Sig. } \\
\hline & & $\mathrm{B}$ & Std. Error & & & \\
\hline \multirow[t]{4}{*}{1} & (Constant) & .202 & .303 & & .665 & .512 \\
\hline & Leverage & .147 & .025 & .698 & 5.829 & .000 \\
\hline & Firm size & -.028 & .035 & -.096 & -.800 & .431 \\
\hline & CAPEX & 056 & .016 & .419 & 3.478 & .002 \\
\hline
\end{tabular}

The results of Table 4 show that the capital expenditures (CAPEX) and the Leverage ratio are statistically significant with values 0.002 and 0.000004 . In addition, they are also positively correlated with the financial performance of 30 Albanian firms in the construction sector of 2008- 2015 period. The size of the firm variable is not statistically significant since the value of $\mathrm{p}$ is greater than 0.05 and it is also negatively correlated with the financial performance. The equation of the regression model is as follows:

$\mathrm{FP}=0.202+0.056$ CAPEX +0.147 Leverage -0.028 Size

\section{Conclusion}

Capital expenditures are carried out in order to benefit economic resources or assets that are used to generate revenue. Therefore, it is important to understand the link between the asset acquisition process and the impact of this process on financial performance.

The study seeks to determine the effect of capital expenditure on the financial performance of 30 Albanian firms in the construction sector, based on the data collection in financial statements of these companies for the period of time from 2008 to 2015.

The study took into consideration the fact that capital expenditures is not the only variable that has an impact on financial performance and as a consequence other variables affecting financial performance were analyzed such as: the leverage ratio, measured by the ratio of total debt to total assets and the size of the firm, measured by the logarithm of the total assets.

According to the study, capital expenditures have a positive correlation to financial performance but the impact is relatively low with a percentage of 5.6. Based on this result we argue that this impact is related to the sector we are considering. Construction firms do not invest much in 
tangible assets since the percentage of change in capital spending from year to year is relatively low. The factor that may have affected is also the blocking of construction permits in the last two years of the study. In conclusion, we can prove that hypothesis 1 stands: capital expenditures have a significant impact on firm's performance.

The second variable taken into consideration is the size of the firm. There is a negative correlation between performance and size of the firm and this correlation is not statistically significant. This negative link is also found in some other studies too. Large and powerful companies declare small profits in proportion to their investments, which can bring about a negative link between these variables. Based on the study, there has been a noticeable decrease in the profits of almost all firms in the last three years.

The third variable studied is the ratio of leverage. According to the results there is a positive, significant relationship between the leverage ratio and the firm's performance. This report explains $20.2 \%$ of the model.

Furthermore, considering debt as a possible way to finance capital expenditures and firm operations would be beneficial if return on investment and working capital exceeds the cost of the debt. Albanian firms in the construction sector during the period 2008-2015 have used the debt to finance capital investment, hence a positive relationship between financial performance and leverage ratio.

Three dependent variables such as,capital expenditure, leverage ratio, and firm size contributed $63 \%$ to the financial performance of 30 firms studied.

The 2008-2009 financial crises brought very dangerous global consequences leading to a very high number of bankruptcies of businesses. The situation seems different in the Albanian construction firms because they have generally made substantial investments in these years and their profits have increased. The slight decline in capital spending may be a recent consequence of the crisis.

There is no evidence of carrying out research and development expenditures in the financial statements in none of the consideration firms operating in Albania. This is justifiable for a developing country as Albania because such spending requires physical, technological, human and financial resources.

\section{References:}

1. Abarbanell, J.S., and Bushee, B.J. (1997). Fundamental Analysis, Future Earnings, and Stock Prices. Journal of Accounting Research, Vol. 35, No.1, 1-24.

2. Cooper, M., H. Gulen, M. Schill, 2008. Asset growth and the cross section of stock returns, Journal of Finance 63, 1609-1651. 
3. Chan, S., J. Martin, and J. Kensinger, 1990, Corporate research and development expenditures and share value, Journal of Financial Economics 26, 255-276.

4. Chen, S., Yao, T., Yu, T., Zhang, T. (2008). Asset growth and stock returns: Evidence from the Pacific-basin markets. Retrieved from International Financial Management Association International.

5. Chung, K.H., Wright, P,. and Charoenwong, C.(1998). "Investment Opportunities and Market Reaction to Capital Expenditure Decisions", Journal of Banking and Finance 22: 41-60.

6. Jiang, C.H., Chen H.L., Huang Y.S., (2006) "Capital expenditures and corporate earnings: Evidence from the Taiwan Stock Exchange", Managerial Finance, Vol. 32 Issue: 11, pp.853-861.

7. Kim, S. (2001), "The near-term financial performance of capital expenditure: a managerial perspective", Managerial Finance, Vol. 27 No. 8, pp. 48-62.

8. Lev, B., and Thiagarajan, S.R. (1993). Fundamental Information Analysis. Journal of Accounting Research, Vol.31, No. 2, 190-215.

9. McConnell, John J. and Chris J. Muscareila (1985). "Corporate Capital Expenditure Decisions and the Market Value of the Firm." Journal of Financial Economics. 14: 399-422.

10. Titman, S., J. Wei, and F. Xie, 2004. Capital investments and stock returns, Journal of Financial and Quantitative Analysis 39, 677-700.

11. http://qkr.gov.al/ Annual Reports. 